\title{
Numerical classification and identification of Bacillus sphaericus including some strains pathogenic for mosquito larvae
}

\author{
Brian Alexander and Fergus G. Priest* \\ Department of Biological Sciences, Heriot Watt University, Riccarton, Edinburgh EH14 4AS, UK
}

(Received 26 June 1989; revised 11 October 1989; accepted 30 October 1989)

\begin{abstract}
Ninety-one strains of Bacillus sphaericus, including representatives of all the established DNA homology groups, related round-spored and oval-spored species, and six strains pathogenic for mosquito larvae, were examined for 155 characters. Numerical analyses (Jaccard coefficient/average linkage clustering) based on the 88 variable features revealed 14 clusters at the $79 \%$ similarity level that contained more than one strain and 17 single member clusters. All insect pathogenic strains were recovered in a single cluster and the classification was in accord with an established classification based on DNA sequence homology. Two frequency matrices for probabilistic identification were constructed and tested. A comprehensive matrix comprising 14 mesophilic, round-spored taxa and 27 tests gave good results for identification of hypothetical median organisms, cluster overlap and identifications of representative strains (based on data generated in the classification study). Reference strains for the 14 taxa and eight additional insect pathogenic strains were examined for the 27 tests and were correctly identified with high scores using this matrix. A second matrix comprising seven taxa and 13 tests also performed well in the theoretical evaluation and correctly identified the reference strains and insect pathogenic strains.
\end{abstract}

\section{Introduction}

Aerobic, rod-shaped bacteria that differentiate into spherical spores have been classified into several species within the genus Bacillus. Ribosomal RNA analyses indicate that these bacteria may represent a separate evolutionary line within the genus (Stackebrandt et al., 1987), and it is notable that most strains are atypical in cell-wall peptidoglycan structure, containing lysine or ornithine rather than meso-2,6-diaminopimelate (mesoDAP; Schleifer \& Kandler, 1972) which is typical of B. subtilis and oval-sporing relatives (Bartlett \& White, 1985). These bacteria are also characterized by negative reactions to most of the traditional phenotypic tests used for the classification and identification of bacilli. This largely arises from their obligately aerobic physiology (an exception is the alkaliphile $B$. pasteurii) and inability to use sugars as sources of carbon and energy (Russell $e t$ al., 1989). As a result, mesophilic, round-spored bacilli that grow at neutral $\mathrm{pH}$ are invariably labelled $B$. sphaericus and the species appears phenotypically homogeneous. This was apparent in a recent numerical classification in which 13 strains were assigned to two closely linked taxa (Priest et al., 1988).

Abbreviations: HMO, hypothetical median organism; meso-DAP; meso-2,6-diaminopimelate.
The heterogeneity of $B$. sphaericus has been revealed by DNA homology studies in which 50 strains were allocated to six homology groups and 12 strains remained ungrouped (Krych et al., 1980). These homology groups have recently been substantiated by multilocus enzyme electrophoresis (Singer, 1988) but diagnostic phenotypic characters have yet to be determined. This is particularly important because members of DNA homology group IIA are pathogenic for some mosquito larvae, in particular certain Aedes, Culex and Mansonia species, and have considerable potential as biological control agents (World Health Organization, 1985; Singer, 1987). At present, these strains can only be distinguished by DNA homology, enzyme electrophoresis or toxicity testing, all of which require a certain level of laboratory sophistication. A small battery of diagnostic phenotypic tests should allow simple identification of potential pathogenic strains.

In this study we have examined 91 strains representing all the $B$. sphaericus DNA homology groups, related reference strains and 32 environmental isolates for 155 phenotypic features. The data were analysed using standard numerical taxonomic procedures and frequency matrices are presented for the probabilistic identification of $B$. sphaericus taxa including the insect pathogenic types. 


\section{Methods}

Strains and isolation conditions. The strains and their sources are given in Table 1. Bacteria were isolated from soil and mud samples using several selective procedures designed for the isolation of $B$. sphaericus strains. All cultures were incubated at $30^{\circ} \mathrm{C}$ unless otherwise stated. Thermophiles were incubated at $50{ }^{\circ} \mathrm{C}$ and psychrophiles at $10^{\circ} \mathrm{C}$. (a) For acetate enrichments, soil suspensions ( $1 \mathrm{~g}$ in $5 \mathrm{ml}$ water) were heated at $60^{\circ} \mathrm{C}$ for $30 \mathrm{~min}$ and incubated in $50 \mathrm{ml} \mathrm{A} 3$ medium
(Massie et al., 1985) for $24 \mathrm{~h}$ with shaking. Samples were plated onto solidified A3 medium and incubated for $48 \mathrm{~h}$. Single colonies from samples were purified and retained.

(b) For adenine enrichments, the same procedure as $(a)$ was followed but the $\left(\mathrm{NH}_{4}\right)_{2} \mathrm{SO}_{4}$ in $\mathrm{A} 3$ medium was replaced by adenine $\left(1 \mathrm{~g} \mathrm{l}^{-1}\right)$. Enrichments were plated and isolates purified on adenine agar.

(c) Creatinine enrichments were based on $\mathrm{A} 3$ medium with acetate replaced by citrate $\left(5 \mathrm{~g} \mathrm{l}^{-1}\right)$ and $2.5 \mathrm{ml} 20 \%(\mathrm{w} / \mathrm{v})$ creatinine $1^{-1}$ in place of $\left(\mathrm{NH}_{4}\right)_{2} \mathrm{SO}_{4}$ as nitrogen source. Enrichment broths were plated and isolates purified on creatinine agar or nutrient agar as indicated.

\section{Table 1. Designation and sources of strains assigned to clusters defined in Fig. 1 (at $79 \%$, UPGMA)}

Binomials in inverted commas are not on the Approved Lists of Bacterial Names (Skerman et al., 1980) and have not been validly published since 1 January 1980. Type strains are marked with an asterisk (*). Strains prefixed 'S' have been described previously (Priest et al., 1988). Other strains were isolated using acetate (Ac), adenine (Ad), creatinine (Cr), creatinine-nutrient agar (Cr-NA), chloramphenicol/lincomycin (Cl) and BATS medium (see Methods) from woodland soil in E. Lothian, Scotland, UK and Corfu, Greece and mud from River Tyne (E. Lothian) and Smeaton Loch (E. Lothian).

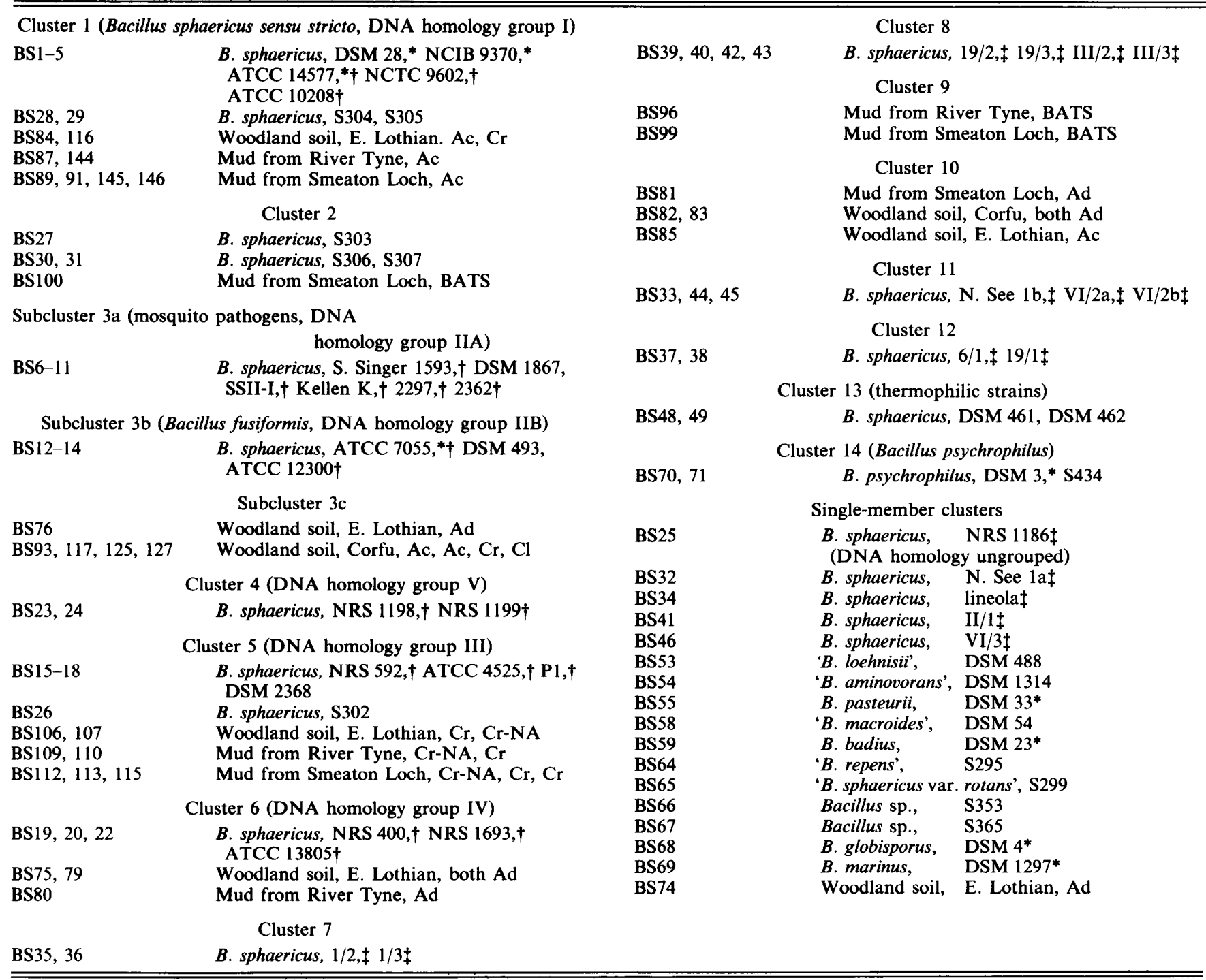

† A. A. Yousten, Microbiology Section, Biology Department, Virginia Polytechnic Institute and State University, Blacksburg, Virginia 24061, USA.

‡ Strain from DSM, Deutsche Sammlung von Mikroorganismen, Braunschweig, FRG. 
Table 2. Percentage distribution of positive diagnostic characters to mesophilic clusters defined at $79 \%$ level $\left(S_{\mathrm{J}}\right)$

\begin{tabular}{|c|c|c|c|c|c|c|c|c|c|c|c|c|c|c|}
\hline \multirow[b]{2}{*}{$\begin{array}{r}\text { Cluster number ... } \\
\text { DNA homology group* ... } \\
\text { Number of strains ... }\end{array}$} & \multicolumn{14}{|c|}{ Taxon } \\
\hline & $\begin{array}{r}1 \\
I \\
15\end{array}$ & $\frac{2}{4}$ & $\begin{array}{r}3 \mathrm{a} \\
\text { IIA } \\
6\end{array}$ & $\begin{array}{c}3 \mathrm{~b} \\
\text { IIB } \\
3\end{array}$ & $\begin{array}{c}3 \mathrm{c} \\
- \\
5\end{array}$ & $\begin{array}{r}4 \\
V \\
2\end{array}$ & $\begin{array}{r}5 \\
\text { III } \\
12\end{array}$ & $\begin{array}{r}6 \\
\text { IV } \\
6\end{array}$ & $\begin{array}{l}7 \\
- \\
2\end{array}$ & $\begin{array}{c}8 \\
- \\
4\end{array}$ & $\begin{array}{c}9 \\
- \\
2\end{array}$ & $\begin{array}{c}10 \\
- \\
4\end{array}$ & $\begin{array}{c}11 \\
- \\
3\end{array}$ & $\begin{array}{c}12 \\
- \\
2\end{array}$ \\
\hline Degradation of: & & & & & & & & & & & & & & \\
\hline $\begin{array}{l}\text { 1. Adenine } \dagger \\
\text { 2. Casein } \dagger \\
\text { 3. Gelatin } \dagger \\
\text { 4. Urea } \dagger\end{array}$ & $\begin{array}{r}1 \\
67 \\
93 \\
1\end{array}$ & $\begin{array}{r}1 \\
25 \\
50 \\
1\end{array}$ & $\begin{array}{l}67 \\
99 \\
99 \\
99\end{array}$ & $\begin{array}{l}1 \\
99 \\
99 \\
99\end{array}$ & $\begin{array}{r}1 \\
80 \\
99 \\
99\end{array}$ & $\begin{array}{r}1 \\
50 \\
99 \\
99\end{array}$ & $\begin{array}{r}1 \\
8 \\
1 \\
58\end{array}$ & $\begin{array}{r}1 \\
1 \\
99 \\
17\end{array}$ & $\begin{array}{l}1 \\
1 \\
1 \\
1\end{array}$ & $\begin{array}{r}1 \\
1 \\
1 \\
99\end{array}$ & $\begin{array}{r}1 \\
99 \\
99 \\
1\end{array}$ & $\begin{array}{r}1 \\
25 \\
25 \\
1\end{array}$ & $\begin{array}{l}1 \\
1 \\
1 \\
1\end{array}$ & $\begin{array}{l}1 \\
1 \\
1 \\
1\end{array}$ \\
\hline $\begin{array}{l}\text { Resistance to }\left(\mu g \mathrm{ml}^{-1}\right) \\
\text { 5. Cephalexin (5) } \\
\text { 6. Chloramphenicol (8) } \\
\text { 7. Erythromycin (1) } \dagger \\
\text { 8. Fusidic acid (5) } \\
\text { 9. Streptomycin (150)† } \\
\text { 10. Tetracycline (2) } \\
\text { 11. Trimethoprim (30) } \dagger \\
\text { 12. Tobramycin (5) }\end{array}$ & $\begin{array}{r}13 \\
7 \\
13 \\
27 \\
99 \\
67 \\
99 \\
7\end{array}$ & $\begin{array}{l}50 \\
25 \\
50 \\
99 \\
99 \\
99 \\
99 \\
99\end{array}$ & $\begin{array}{r}83 \\
99 \\
1 \\
99 \\
99 \\
99 \\
99 \\
1\end{array}$ & $\begin{array}{l}67 \\
99 \\
99 \\
99 \\
99 \\
99 \\
99 \\
67\end{array}$ & $\begin{array}{l}99 \\
99 \\
99 \\
99 \\
80 \\
99 \\
99 \\
40\end{array}$ & $\begin{array}{r}50 \\
1 \\
1 \\
99 \\
99 \\
50 \\
1 \\
99\end{array}$ & $\begin{array}{r}83 \\
83 \\
99 \\
99 \\
1 \\
75 \\
92 \\
99\end{array}$ & $\begin{array}{r}50 \\
1 \\
99 \\
99 \\
99 \\
83 \\
86 \\
1\end{array}$ & $\begin{array}{r}99 \\
1 \\
99 \\
99 \\
1 \\
50 \\
99 \\
99\end{array}$ & $\begin{array}{r}99 \\
25 \\
50 \\
99 \\
1 \\
50 \\
99 \\
50\end{array}$ & $\begin{array}{r}1 \\
50 \\
1 \\
99 \\
99 \\
99 \\
99 \\
99\end{array}$ & $\begin{array}{r}1 \\
1 \\
1 \\
1 \\
99 \\
1 \\
99 \\
1\end{array}$ & $\begin{array}{r}99 \\
1 \\
99 \\
99 \\
33 \\
1 \\
99 \\
1\end{array}$ & $\begin{array}{r}1 \\
1 \\
99 \\
50 \\
1 \\
50 \\
50 \\
1\end{array}$ \\
\hline $\begin{array}{l}\text { Utilization of }(0 \cdot 2 \% w / v) \text { : } \\
\text { 13. Glycerate } \\
\text { 14. } \alpha \text {-Oxoglutarate } \\
\text { 15. Tartrate }\end{array}$ & $\begin{array}{l}13 \\
33 \\
13\end{array}$ & $\begin{array}{l}75 \\
75 \\
75\end{array}$ & $\begin{array}{r}99 \\
33 \\
1\end{array}$ & $\begin{array}{r}99 \\
1 \\
1\end{array}$ & $\begin{array}{r}1 \\
80 \\
60\end{array}$ & $\begin{array}{r}1 \\
99 \\
1\end{array}$ & $\begin{array}{l}42 \\
75 \\
50\end{array}$ & $\begin{array}{l}50 \\
33 \\
17\end{array}$ & $\begin{array}{r}99 \\
99 \\
1\end{array}$ & $\begin{array}{r}1 \\
75 \\
1\end{array}$ & $\begin{array}{r}50 \\
1 \\
1\end{array}$ & $\begin{array}{r}1 \\
25 \\
1\end{array}$ & $\begin{array}{r}67 \\
33 \\
1\end{array}$ & $\begin{array}{r}50 \\
1 \\
1\end{array}$ \\
\hline $\begin{array}{l}\text { Utilization of }(0.4 \% w / v) \text { : } \\
\text { 16. D- } \alpha \text {-Alanine } \\
\text { 17. L- } \alpha-\text { Alanine } \\
\text { 18. Citraconate } † \\
\text { 19. Cytosine } \\
\text { 20. Ethanolamine } \\
\text { 21. L-Isoleucine } \\
\text { 22. L-Leucine } \dagger \\
\text { 23. L-Serine† } \ddagger \\
\text { 24. L-Threonine† }\end{array}$ & $\begin{array}{r}93 \\
87 \\
1 \\
99 \\
99 \\
99 \\
99 \\
99 \\
99\end{array}$ & $\begin{array}{r}99 \\
50 \\
1 \\
99 \\
99 \\
25 \\
99 \\
99 \\
99\end{array}$ & $\begin{array}{r}67 \\
83 \\
67 \\
99 \\
33 \\
1 \\
99 \\
1 \\
50\end{array}$ & $\begin{array}{r}1 \\
1 \\
99 \\
99 \\
1 \\
1 \\
99 \\
33 \\
1\end{array}$ & $\begin{array}{r}99 \\
99 \\
1 \\
99 \\
99 \\
60 \\
99 \\
80 \\
99\end{array}$ & $\begin{array}{r}1 \\
1 \\
1 \\
99 \\
1 \\
99 \\
1 \\
99 \\
99\end{array}$ & $\begin{array}{r}99 \\
58 \\
1 \\
99 \\
83 \\
67 \\
1 \\
99 \\
99\end{array}$ & $\begin{array}{r}67 \\
67 \\
1 \\
99 \\
99 \\
50 \\
33 \\
99 \\
99\end{array}$ & $\begin{array}{r}99 \\
1 \\
99 \\
99 \\
99 \\
1 \\
99 \\
99 \\
99\end{array}$ & $\begin{array}{r}1 \\
1 \\
1 \\
99 \\
1 \\
75 \\
99 \\
99 \\
99\end{array}$ & $\begin{array}{r}1 \\
1 \\
1 \\
99 \\
1 \\
1 \\
1 \\
50 \\
50\end{array}$ & $\begin{array}{r}1 \\
1 \\
1 \\
33 \\
1 \\
1 \\
1 \\
1 \\
99\end{array}$ & $\begin{array}{r}1 \\
1 \\
1 \\
1 \\
99 \\
1 \\
1 \\
99 \\
67\end{array}$ & $\begin{array}{r}1 \\
99 \\
1 \\
1 \\
99 \\
1 \\
1 \\
99 \\
1\end{array}$ \\
\hline $\begin{array}{l}\text { Growth in }(\%, w / v) \text { : } \\
25 . \mathrm{NaCl}(7) \\
\text { 26. Thallous acetate }(0 \cdot 01) \dagger \\
\text { 27. Crystal violet }(0 \cdot 0001)\end{array}$ & $\begin{array}{r}1 \\
73 \\
47\end{array}$ & $\begin{array}{r}1 \\
75 \\
25\end{array}$ & $\begin{array}{l}99 \\
99 \\
99\end{array}$ & $\begin{array}{l}99 \\
99 \\
33\end{array}$ & $\begin{array}{l}99 \\
99 \\
60\end{array}$ & $\begin{array}{r}50 \\
1 \\
1\end{array}$ & $\begin{array}{r}50 \\
1 \\
99\end{array}$ & $\begin{array}{r}67 \\
1 \\
83\end{array}$ & $\begin{array}{l}50 \\
99 \\
99\end{array}$ & $\begin{array}{l}75 \\
50 \\
99\end{array}$ & $\begin{array}{r}99 \\
1 \\
99\end{array}$ & $\begin{array}{r}1 \\
25 \\
50\end{array}$ & $\begin{array}{r}33 \\
1 \\
99\end{array}$ & $\begin{array}{r}99 \\
1 \\
99\end{array}$ \\
\hline $\begin{array}{l}\text { Growth at: } \\
\text { 28. pH 5.0 }\end{array}$ & 67 & 50 & 99 & 99 & 99 & 99 & 99 & 99 & 99 & 99 & 25 & 1 & 1 & 1 \\
\hline $\begin{array}{l}\text { Miscellaneous tests: } \\
\text { 29. Chymotrypsin }\end{array}$ & 99 & 75 & 99 & 99 & 99 & 99 & 92 & 33 & 1 & 50 & 1 & 1 & 99 & 99 \\
\hline
\end{tabular}

* DNA homology groups of Krych et al. (1980)

† The 13 characters tested used in the smaller matrix for clusters $1,3 a, 3 b, 3 c, 4,5$ and 6.

$\ddagger$ Characters used only in the 13 test matrix.

(d) BATS medium was inoculated directly with pasteurized soil samples as described by Yousten et al. (1985).

(e) Streptomycin/lincomycin agar (Kalfon et al., 1986) was inoculated directly with pasteurized soil. Lincomycin was replaced by chloramphenicol $\left(6 \mu \mathrm{g} \mathrm{ml}^{-1}\right)$ in streptomycin/chloramphenicol agar and chloramphenicol/lincomycin agar contained chloramphenicol $\left(6 \mu \mathrm{g} \mathrm{ml}^{-1}\right)$ instead of streptomycin. Both were inoculated directly with pasteurized soil.

All strains were purified by replating and stored as cell/spore suspensions in $20 \%(\mathrm{v} / \mathrm{v})$ glycerol at $-20^{\circ} \mathrm{C}$.

Phenotypic tests. Bacteria were grown on nutrient agar for $48 \mathrm{~h}$ and visibly turbid suspensions were prepared in saline $(0.85 \%)$. Media in Petri dishes, or Replidishes (Sterilin), as appropriate (see Priest $e t$ al., 1988), were inoculated using a multipoint inoculator (Denley) and incubated for $5 \mathrm{~d}$ unless stated otherwise. Test procedures have been described in detail (Priest et al., 1988); additions and amendments where appropriate are given below.

Morphological tests. The following were of little or no diagnostic value : colonies flat/raised, smooth, rhizoidal, entire, opaque, motile or pigmented; cell length; ends pointed; Gram reaction; spore shape; spore position or swelling of sporangium.

Degradation tests. The following characters had little or no diagnostic 
potential. Hydrolysis of: carboxymethylcellulose (Alexander \& Priest, 1989); chondroitin ( $0.4 \%$ in nutrient agar), detected by flooding plates after incubation for $4 \mathrm{~d}$ with $1 \%(\mathrm{w} / \mathrm{v})$ cetyltrimethylammonium bromide; creatinine (detected as an alkaline reaction after incubation for $2 \mathrm{~d}$ in Christensen's urease medium with the urea replaced by $1 \%$, w/v, filter-sterilized creatinine); DNA; elastin; hypoxanthine; testosterone; Tween 20; Tween 80; degradation of uric acid and xanthine. Tests with diagnostic value are given in Table 2 .

Antibiotic resistance tests. All antibiotics were supplied by Sigma and included in nutrient agar at the concentrations indicated in Table 2. Good growth after incubation for $4 \mathrm{~d}$ was scored as positive. The following antibiotics $\left(\mu \mathrm{g} \mathrm{ml}^{-1}\right)$ were of little or no diagnostic value: cephaloridine (25), clindamycin (5), colistin sulphate (25), cycloserine (128), gentamycin (5), gramicidin (64), kanamycin (10), lincomycin (30), nalidixic acid (64), nitrofurantoin (25), novobiocin (5), penicillin (4), polymyxin (16), rifampicin $(0 \cdot 125)$, spectinomycin (5), sulphonamide (30) and vancomycin (5).

Utilization of organic acids. The medium of Gordon et al. (1973) was used. Growth accompanied by a change in indicator colour after incubation for $4 \mathrm{~d}$ was recorded as a positive reaction. The list of organic acids tested comprises the characters given in Table 2 and the following, which were of little or no diagnostic value: acetate, butyrate, hydroxybutyrate, citrate, formate, fumarate, gluconate, hydroxymethyl glutarate, lactate, malate, pyruvate and succinate.

Utilization of sole sources of carbon. The organic acid medium was supplemented with various carbon sources (Table 2 and see below) at $0.4 \%(w / v)$. Growth after incubation for $4 \mathrm{~d}$ indicated a positive response. Tests for utilization of the following had poor or no diagnostic value: acetamide, adipic acid, $\beta$-alanine, $m$-aminobenzoate, DLaminobutyrate, amylamine, anthranilate, $\mathrm{L}$-arginine, L-asparagine, betaine, L-aspartate, choline citrate, L-citrulline, ergosterol, glycerol, glycine, glucosamine, D-glucose, L-glutamate, L-glutamine, L-histidine, L-hydroxybenzoate, levulinate, mesaconate, nicotinamide, L-norvaline, L-ornithine, L-proline, D-ribose, L-tyrosine and L-valine.

Tolerance tests. Growth in the presence of various compounds (Table 2 and see below) was examined using nutrient agar supplemented appropriately; growth after incubation for $4 \mathrm{~d}$ was considered a positive response. The following had no diagnostic value [growth in the presence of $(\%, w / v)$ ]: phenol $(0 \cdot 1)$, phenylethanol $(0 \cdot 1$, $0 \cdot 3)$, potassium tellurite $(0.01,0.001)$, sodium chloride $(5,10)$, sodium azide $(0.01,0.02)$ and thallous acetate $(0.001)$. Tests for growth at 20,40 and $50{ }^{\circ} \mathrm{C}$ on nutrient agar, and at $\mathrm{pH} 5.5,6.0$ and 6.5 showed little diagnostic potential.

Enzyme substrates. Ability to hydrolyse a range of nitrophenyl sugar derivatives was examined according to the method described by Cowan (1974) for $o$-nitrophenyl $\beta$-D-galactoside hydrolysis using 96well microtitre trays. Cells were incubated with substrate for $18 \mathrm{~h}$ before addition of $0.5 \mathrm{M}$-sodium carbonate. The following substrates were uniformly negative: $p$-nitrophenyl $(p \mathrm{~N})$-acetate, $p \mathrm{~N}$-anthranilate, $p \mathrm{~N}-\alpha$-L-fucopyranoside, $p \mathrm{~N}$ - $\alpha$-D-galactopyranoside, $o \mathrm{~N}-\beta$-D-galactopyranoside, $p \mathrm{~N}$ - $\alpha$-D-glucopyranoside, $p \mathrm{~N}-\beta$-D-glucopyranoside, $p \mathrm{~N}-\beta$ $\mathrm{D}$-glucuronide, $p \mathrm{~N}$-laurate, $p \mathrm{~N}-\alpha$-D-mannopyranoside, $p \mathrm{~N}-\beta$-D-mannopyranoside, $p \mathrm{~N}$-myristate, $p \mathrm{~N}$ - $\alpha$-D-xylopyranoside and $o \mathrm{~N}-\beta$-D-xylopyranoside. Chymotrypsin- and trypsin-like activities were detected by incubating multipoint inoculated nutrient agar plates for $48 \mathrm{~h}$ and overlaying with semi-solid agar containing $N$-glutaryl-L-phenylalanine$p$-nitroanilide and $N$-benzoyl-DL-p-nitroanilide (both $1 \mathrm{mg} \mathrm{ml}^{-1}$ ). A yellow colour after incubation for $6 \mathrm{~h}$ was scored positive.

Miscellaneous tests. Cells were analysed for the presence of lysine in cell walls using the method described by Kandler \& Weiss (1986). The following tests had little or no diagnostic potential: reduction of nitrate, phenylalanine deamination, phosphatase activity, arginine dihydrolase activity, dihydroxyacetone reaction and indole production.

Data analysis. Twelve strains were duplicated and test results were analysed according to Sneath \& Johnson (1972) to provide an assessment of test error. Results for tests that were either positive or negative for all strains were excluded from the computation. The final matrix therefore comprised data for 91 strains and 88 tests. Data were scored in binary code and analysed using the Clustan IC package Release 2 (Wishart, 1978) on a Vax cluster computer. Two proximity coefficients (Jaccard, $S_{\mathrm{J}}$, and simple matching, $S_{\mathrm{SM}}$ were calculated and similarity matrices were clustered using the unweighted pair group method with arithmetic averages (UPGMA) algorithm (see Sneath \& Sokal, 1973 for details). Cophenetic correlation was determined for the two dendrograms using Clustan.

The frequency matrix (Table 2) was analysed using CHARSEP (Sneath, $1979 b$ ) and DIACHAR (Sneath, 1980a) which calculate character separation indices and most diagnostic tests for clusters, respectively. From this information, two frequency matrices were prepared for probabilistic identification. The larger matrix was tested for cluster overlap using OVERMAT (Sneath, 1980c) and hypothetical median organisms (HMOs) were calculated and identified using MOSTTYP (Sneath, 1980b). Test results were redetermined for cluster representatives and some additional strains, which were identified using MATIDEN (Sneath, 1979a). Use of these programs has been described previously (Priest \& Alexander, 1988).

\section{Results}

\section{Numerical classification}

Results for the 12 duplicated strains indicated an overall probability of test error of $1 \%$. The two computations gave slightly different classifications as indicated below. The relationships between clusters differed slightly in that cluster 4 of the $S_{\mathrm{J}}$ analysis was recovered between clusters 8 and 9 in the $S_{\mathrm{SM}}$ dendrogram (Fig. 1).

The 91 strains were recovered in 14 clusters containing more than one strain and 17 single member clusters at the $79 \% S_{\mathrm{J}}$ level which corresponded to 14 clusters and 12 single member clusters at $87 \% S_{\mathrm{SM}}$. The two dendrograms showed 0.952 and 0.935 cophenetic correlation respectively and consequently the $S_{\mathrm{J}}$ /UPGMA dendrogram was considered to reflect the most accurate classification. Table 2 does not include data for the two thermophilic and two psychrotrophic strains (clusters 13 and 14 respectively in Fig. 1) since the study concentrates on the classification and identification of mesophilic strains likely to be recovered under normal isolation conditions. Nevertheless, these bacteria and the oval-spored reference strains are included in Fig. 1 to demonstrate the relationships between them.

Both dendrograms closely resembled the classification based on DNA homology determined by Krych et al. (1980). The following description will concentrate on the $S_{\mathrm{J}} /$ UPGMA analysis. Cluster 1 contained the type strain of 


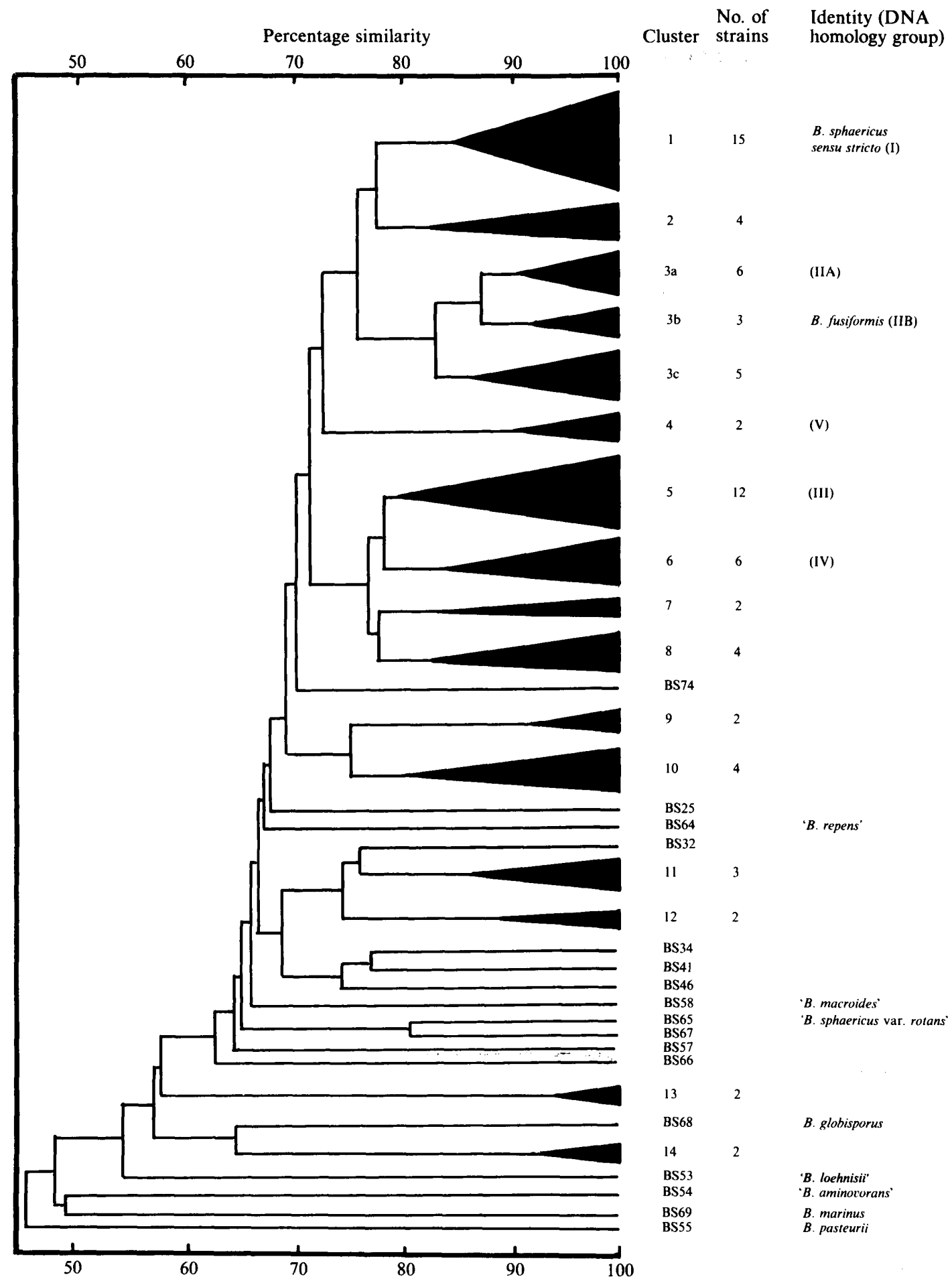

Fig. 1. Simplified dendrogram showing the relationship between clusters recovered in the $S_{\mathrm{J}} /$ UPGMA analysis.

B. sphaericus and strains belonging to DNA homology group I. This cluster represents $B$. sphaericus sensu stricto. These strains hydrolysed casein, gelatin and Tween 80 and were resistant to high levels of streptomycin and trimethoprim. They did not hydrolyse urea but grew on a range of organic acids and amino acids, notably acetate and arginine which are used in selective media for these bacteria. Indeed, of the eight environmental isolates in 
this cluster, seven were isolated using acetate as a selective carbon source.

Cluster 2 contained three strains from our laboratory collection that had clustered with $B$. sphaericus in a previous study (Priest et al., 1988), and an environmental isolate. In the $S_{\mathrm{SM}}$ computation it also contained strains BS35 and BS36 which were supplied by the DSM and had been isolated from soil using casein enrichments. The few tests which separated this cluster from cluster 1 included tartrate and glycerate utilization and tobramycin resistance.

Cluster 3 was divided into three subclusters in accord with the DNA homology groups reported by Krych et al. (1980). All the insect pathogenic strains (DNA homology group IIA) included in the study were recovered in subcluster $3 \mathrm{a}$ in both computations. These joined subcluster $3 \mathrm{~b}$ at the $85.5 \% S_{\mathrm{J}}$ level corresponding to $90 \%$ $S_{\mathrm{SM}}$. Subcluster $3 \mathrm{~b}$ contained strains from DNA homology group IIB (Krych et al., 1980) that represent $B$. fusiformis. The major distinction between strains of subclusters $3 \mathrm{a}$ and $3 \mathrm{~b}$ was the ability of most strains in subcluster $3 a$ to clear adenine from nutrient agar. Indeed, no other strains in the study could do this. Subcluster 3a strains were resistant to streptomycin and chloramphenicol which are used in selective media for these bacteria. They could be distinguished from $B$. sphaericus sensu stricto by the ability to hydrolyse urea and, for most strains, to utilize citrate. Strains of subcluster $3 \mathrm{c}$ were isolated using a variety of media, with all but one originating from woodland soil from Corfu, Greece. The subcluster was recovered intact in both computations and recent results (unpublished) show that it comprises a separate DNA homology group.

DNA homology group $\mathrm{V}$ strains were recovered as cluster 4 and the 12 strains in cluster 5 represent DNA homology group III. Of these 12 strains, seven were environmental isolates from creatinine enrichments and the remainder were reference strains. Cluster 6 contained three reference strains from DNA homology group IV and three environmental isolates from adenine enrichments. Clusters 4, 5 and 6 could be distinguished using gelatin hydrolysis, resistance to erythromycin, streptomycin, trimethoprim and tobramycin, growth on ethanolamine, $\mathrm{D}$-alanine and glucosamine and resistance to crystal violet (Table 2).

There were some inconsistencies amongst the two cluster 7 strains which were included in cluster 2 in the $S_{\mathrm{SM}}$ dendrogram. Both were received from the DSM and orginated from casein enrichments. They differed from cluster 2 strains in being resistant to gramicidin, sensitive to streptomycin and failing to grow on tartrate, but showing growth on citraconate and adipic acid. Their status as a separate cluster therefore seems to be valid.
The remaining clusters comprised environmental isolates or strains isolated from casein enrichments and supplied by the DSM. Cluster 9 contained an additional strain (BS72) in the $S_{\mathrm{SM}}$ computation and cluster 10 strains were mainly isolated using adenine enrichments. Two thermotolerant, round-spored strains were recovered in cluster 13 . These bacteria grew at $55^{\circ} \mathrm{C}$ but not at $37^{\circ} \mathrm{C}$. The B. psychrophilus strains were assigned to cluster 14 . These bacteria grew only below $25^{\circ} \mathrm{C}$.

Single-member clusters largely comprised reference strains of round-and oval-spored species. Strain BS25 was ungrouped in both this study and the DNA homology study of Krych et al. (1980). Round-spored strains that failed to cluster included ' $B$. loehnisii', ' $B$. aminovorans', $B$. pasteurii, 'B. repens', 'B. sphaericus var. rotans', $B$. globisporus and $B$. marinus. Oval-spored strains considered to be physiologically related to $B$. sphaericus but which were unclustered included ' $B$. macroides' and $B$. badius. All round-spored strains included in the study with the exception of ' $B$. aminovorans' contained lysine in their cell walls and meso-DAP was not detected. Conversely, the cell walls from the oval-spored strains and ' $B$. aminovorans' contained meso-DAP.

\section{Identification}

The data in Table 2 were used to prepare two matrices for probabilistic identification. We used 14 clusters/subclusters but excluded the thermophiles and psychrophiles since such strains would not be isolated using incubation conditions for B. sphaericus of 30 or $37^{\circ} \mathrm{C}$. The 88 differential characters were evaluated using CHARSEP which provides five different separation indices for assessing the diagnostic value of characters including the VSP index (Sneath, 1979b) which, for useful characters, will be greater than $25 \%$. Twenty-seven characters that possessed VSP $>48.25 \%$ (except adenine degradation, VSP $1 \%$ but essential for identification of cluster 3a) were chosen for the matrix (see Table 2). The 14 taxa in the matrix showed little overlap as assessed by the OVERMAT program (cluster $1 /$ cluster $2=3 \cdot 2 \%$; remainder $<1 \%$ ) and standard deviations for clusters were below 0.245 indicating that they were compact. HMOs were calculated and identified using MOSTTYP. All but one identified with Willcox probabilities of $1 \cdot 0$, the exception being a score of 0.999 for cluster 2 . Taxonomic distance $(D)$ was below $\mathbf{0 . 2 5 7}$ and standard error of taxonomic distance (SED) below -1.07 for the HMOs of all clusters. Sample strains (representing strains from the centres and peripheries of clusters) were identified using the data generated in the numerical classification. All identified with Willcox probabilities $>0.999(D<0.446$ and SE $D<6 \cdot 0$ ). When the test data were re-determined for these strains the values dropped to $>0.986$ for 
Table 3. Identification coefficients for type or reference strains using the two identification matrices

\begin{tabular}{|c|c|c|c|c|}
\hline $\begin{array}{c}\text { Cluster } \\
\text { number }\end{array}$ & $\begin{array}{l}\text { Reference } \\
\text { strain }\end{array}$ & $\begin{array}{c}\text { Willcox } \\
\text { probability† }\end{array}$ & $\begin{array}{c}\text { Taxonomic } \\
\text { distance }(D) \dagger\end{array}$ & SED $D+$ \\
\hline 1. (DNA I) & DSM $28 \ddagger$ & $1.000(1.000)$ & $0 \cdot 311(0 \cdot 125)$ & $0.177(-2.178)$ \\
\hline 2. & S307 & 0.999 & $0 \cdot 328$ & -0.322 \\
\hline 3a. (DNA IIA) & 1593 & $0.999(0.999)$ & $0.180(0.189)$ & $-1.659(-1.075)$ \\
\hline 3b. (DNA IIB) & ATCC 7055 & $1.000(0.999)$ & $0 \cdot 110(0 \cdot 186)$ & $-2.855 \quad(0.867)$ \\
\hline 3c. & BS126 & $1.000(0.999)$ & $0.222(0 \cdot 174)$ & $-1.297 \quad(0.189)$ \\
\hline 4. (DNA V) & NRS 1198 & $1.000(0.999)$ & $0.192(0.196)$ & $-0.599(-0.374)$ \\
\hline 5. (DNA III) & NRS 592 & $1.000(0.999)$ & $0.375(0.183)$ & $1.658(-1.040)$ \\
\hline 6. (DNA IV) & NRS 400 & $0.999(0.999)$ & $0.343(0.312)$ & $0.700 \quad(1.345)$ \\
\hline 7. & $1 / 3$ & 0.999 & 0.239 & -0.531 \\
\hline 8. & III $/ 2$ & 0.998 & 0.348 & 0.581 \\
\hline 9. & BS99 & 0.999 & $0 \cdot 233$ & $2 \cdot 227$ \\
\hline 10. & BS82 & 1.000 & $0 \cdot 147$ & $-2 \cdot 538$ \\
\hline 11. & $\mathrm{VI} / 2 \mathrm{a}$ & 0.999 & 0.213 & $-0 \cdot 172$ \\
\hline 12. & $6 / 1$ & 0.999 & $0 \cdot 371$ & $0 \cdot 381$ \\
\hline
\end{tabular}

* DNA homology groups of Krych et al. (1980) are shown in parentheses.

$\dagger$ Figures in parentheses are identification coefficients obtained with the small (13 character) matrix.

$\ddagger$ Type strain.

Table 4. Identification coefficients for some mosquito pathogenic strains of B. sphaericus

\begin{tabular}{|c|c|c|c|c|}
\hline Strain* & Identification & $\begin{array}{c}\text { Willcox } \\
\text { probability }\end{array}$ & $\begin{array}{c}\text { Taxonomic } \\
\text { distance }(D) \dagger\end{array}$ & SED $D \dagger$ \\
\hline WHO 1883 & Taxon 3a (DNA IIA) & $0.999(0.988)$ & $0 \cdot 266(0 \cdot 147)$ & $0.815(-1.944)$ \\
\hline WHO $2013 \cdot 6$ & Taxon 3a (DNA IIA) & $0.999(0.999)$ & $0.424(0.216)$ & $5.590(-0.526)$ \\
\hline WHO 2115 & Taxon 3a (DNA IIA) & $0.984(0.971)$ & $0.266(0.347)$ & $0.815 \quad(2.181)$ \\
\hline WHO 2173 & Taxon 3a (DNA IIA) & $0.999(0.999)$ & $0.379(0.346)$ & $4 \cdot 221 \quad(2 \cdot 155)$ \\
\hline WHO 2314.2 & Taxon 3a (DNA IIA) & $0.996(0.988)$ & $0.380(0.392)$ & $4 \cdot 250 \quad(3 \cdot 107)$ \\
\hline WHO 2315 & Taxon 3a (DNA IIA) & $0.999(0.999)$ & $0.364(0.236)$ & $3.768(-0.114)$ \\
\hline WHO 2377 & Taxon 3a (DNA IIA) & $0.999(0.999)$ & $0.395(0.392)$ & $4.713 \quad(3.107)$ \\
\hline WHO 2500 & Taxon 3a (DNA IIA) & $0.999(0.999)$ & $0.379(0.147)$ & $4.221(-1.944)$ \\
\hline
\end{tabular}

*All strains were supplied by A. A. Yousten, Microbiology Section, Biology Department, Virginia Polytechnic Institute and State University, Blacksburg, Virginia 24061, USA.

$\dagger$ Figures in parentheses are identification coefficients obtained using the small (13 character) matrix.

Willcox probabilities and $<0.459$ and $<7.0$ for $D$ and SE $D$, respectively. These poor values for $D$ and SE $D$ were for clusters 7,9 and 12 and clusters 1 to 6 consistently obtained good scores $(<0.436$ and $<4.13$, respectively). Type or reference strains were re-tested for the 27 characters. All identified well to their clusters (Table 3). Some strains supplied as probable insect pathogens were also examined for the 27 tests and all identified to subcluster 3a (DNA homology group IIA) with acceptable scores (Table 4).

When identifying field isolates suspected to be insect pathogens, the full battery of 27 tests may not be necessary. We tested a second matrix based on the clusters that represent the established DNA homology groups only and taxon $3 \mathrm{c}$. The matrix therefore comprised seven taxa (clusters 1, 3a, 3b, 3c, 4, 5 and 6) and 13 tests (Table 2). This matrix performed remark- ably well. Overlap was below $1 \%$ for all taxa (using OVERMAT) and HMOs identified with high scores (Willcox probabilities 0.998-1.0). Identification coeffcients for cluster representatives were acceptable before and after re-determination of the characters, and all reference strains were identified (Table 3). Of particular note, suspected insect pathogenic strains identified to cluster 3a (DNA homology group IIA) with high scores (Table 4).

\section{Discussion}

Studies of DNA homology and enzyme electrophoresis have consistently revealed diversity amongst roundspored bacilli, despite apparent phenotypic homogeneity (Krych et al., 1980; Singer, 1988). Some of the taxa 
within $B$. sphaericus can be distinguished by using test methods based on carbon-source utilization rather than acid production from carbohydrates (de Barjac et al., 1980; Baumann et al., 1984) but the use of such methods alone does not enable complete phenotypic demarcation of the DNA homology groups. The combination of carbon-source utilization tests and other physiological and biochemical characters used in this study has provided a phenotypic classification that is completely compatible with that based on DNA homology and has enabled the separation of several clusters (e.g. 1,2 and 5) which contain strains that in a previous study were combined as B. sphaericus (Priest et al., 1988). Thus in this study, each of the homology groups was recovered in its entirety and each probably represents a species.

The insect pathogenic strains were all allocated to subcluster $3 \mathrm{a}$. This could be considered a distinct species since it is phenotypically and genetically distinct from $B$. sphaericus sensu stricto (cluster 1), but the separation from B. fusiformis (subcluster $3 b$ ) is poor. There is still a lack of good diagnostic characters for subcluster $3 a$; clearance of adenine from nutrient agar, citrate utilization and sensitivity to erythromycin are the three most useful features. Nevertheless, insect pathogenic strains were consistently assigned to subcluster $3 \mathrm{a}$ using both identification matrices. It is interesting to compare the relationships within cluster 3 with the situation pertaining to the other important insect pathogenic sporeformer, $B$. thuringiensis. $B$. thuringiensis strains are virtually indistinguishable from $B$. cereus using phenotypic features but numerical classification reveals separate subclusters at about the $\mathbf{9 0} \%$ similarity level (Priest et al., 1988). Moreover, there is considerable DNA homology between strains of $B$. thuringiensis and $B$. cereus (Somerville \& Jones, 1972) and, like 3a and 3b strains, thermal denaturation studies suggest that this represents poorly matched hybrids. Crystal-protein genes are generally plasmid-borne in $B$. thuringiensis (Aronson et al., 1986) but, although many of the pathogenic strains of ' $B$. sphaericus' contain one or several large plasmids (Singer, 1988), the locations of the crystal-protein genes have yet to be determined (Baumann et al., 1987; Hindley \& Berry, 1987). Finally, $B$. thuringiensis strains can be allocated to serotypes (de Barjac, 1981). Similarly, strains within subcluster 3a have been grouped by phage typing (Yousten, 1984) and serology (de Barjac et al., 1980) and the groups correlate well with insect toxicity. Since the name $B$. thuringiensis has been retained for what many people believe to be 'insect pathogenic strains of B. cereus', and this has value for insect pathologists, so it could be argued that the insect pathogenic strains related to $B$. fusiformis be given species status.

We isolated strains from soils in Eastern Scotland that clustered with DNA homology group I strains (cluster 1 strains; B. sphaericus sensu stricto), group III strains (cluster 5) and group IV strains (cluster 6) but not homology groups IIA, IIB or V (subclusters 3a, 3b and 4 respectively). This may be due to inappropriate selective isolation, since cluster 1 environmental isolates, with one exception, were recovered using acetate as principal carbon source; cluster 5 strains were all isolated from creatinine enrichments, and cluster 6 strains from adenine plates. Alternatively, inability to recover cluster $3 \mathrm{a}, 3 \mathrm{~b}$ and 4 strains from local samples might reflect scarcity of these strains in northern latitudes; all insect pathogens to date have been derived from either diseased insect larvae or soil/mud samples from countries having Mediterranean-type or tropical climates (Lysenko et al., 1985; Brownbridge \& Margalit, 1987).

Although the enrichment of cluster 5 strains with creatinine seems to contradict the phenotypic test in which all strains were recorded negative for creatinine hydrolysis, the latter was tested as an alkaline reaction. Presumably, these strains do not hydrolyse creatinine using the iminohydrolase pathway that produces $N$ methylhydantoin and ammonia from the substrate (Szulmajster, 1958; Esders \& Lynn, 1985) and use the reactions involving $N$-methylhydantoin and sarcosine as exemplified by Clostridium sordellii (Möller et al., 1986), or some other pathway which does not result in an appreciable increase in $\mathrm{pH}$.

Other enrichment methods did not prove particularly successful in this study. Strains isolated on BATS medium, which is intended to be selective for insect pathogens (Yousten et al., 1984), were recovered in clusters 2 and 9. Streptomycin/lincomycin (Kalfon et al., 1986) and streptomycin/chloramphenicol agars failed to recover any round-spored strains and the isolates BS125 and BS127 from chloramphenicol/lincomycin agar were recovered in cluster 3c. Again, it is possible that the failure of lincomycin/streptomycin and BATS media was due to the scarcity of insect pathogenic strains in our local samples. Nevertheless, there is certainly a need for better selective media. Since only the mosquito pathogens cleared adenine from nutrient agar plates (Table 2), we are currently evaluating various medium formulations based on purines and their derivatives.

Cluster patterns of the reference strains were in accord with other studies (Claus \& Berkeley, 1986; Priest et al., 1988). The only round-spored strain that contained mesoDAP in its cell wall was ' $B$. aminovorans' and this strain showed very little phenotypic similarity to the other round-spored strains. Ribosomal RNA cataloguing also shows that this bacterium has diverged significantly from B. sphaericus (Stackebrandt et al., 1987). Recovery of $B$. marinus, 'B. aminovorans' and $B$. globisporus in separate clusters substantiates other studies (Rüger, 
1983; Nakamura, 1984) and confirms the existence of several species with round spores. Similarly, the absence of phenetic similarity with the oval-spored strains indicates that the separate lineages of oval- and roundspored strains is reflected in their phenotypes.

The classification described here formed the basis of a reliable identification system. The large matrix should prove useful for the general identification of mesophilic bacilli that form round spores. The theoretical evaluation of this matrix proved it to be robust, and the practical testing using reference strains indicated that it will be of general use. The smaller matrix, on the other hand, should be of great value to those involved in identifying insect pathogenic strains. The scores obtained with this matrix were acceptable, being well within the limits for identification scores set in other studies (e.g. Williams $e t$ al., 1985; Priest \& Alexander, 1988). It is anticipated that this matrix. will be particularly useful when identifying restricted selections of strains recovered, for example, from selective isolation plates or diseased insects.

We are very grateful to Allan Yousten for the provision of strains and to the Deutsche Sammlung von Mikroorganismen for financial support.

\section{References}

AleXander, B. \& Priest; F. G. (1989). Bacillus glucanolyticus, a new species that degrades a variety of $\beta$-glucans. International Journal of Systematic Bacteriology 39, 112-115.

ARonson, A. I., BeCKMAN, W. \& DUNN, P. (1986). Bacillus thuringiensis and related insect pathogens. Microbiological Reviews 50, 1-24.

DE BARJAC, H. J. (1981). Insect pathogens in the genus Bacillus. In The Aerobic Endospore-forming Bacteria: Classification and Identification, pp. 241-250. Edited by R. C. W. Berkeley \& M. Goodfellow. New York: Academic Press.

de Barjac, H. J., Véron, M. \& Cosmao-Dumanoir, V. (1980). Characterization biochemique et sérologique de souches de Bacillus sphaericus pathogènes ou non pour les moustiques. Annales de Microbiologie 131B 191-201.

Bartlett, A. T. M. \& White, P. J. (1985). Species of Bacillus that make a vegetative peptidoglycan containing lysine lack diaminopimelate epimerase but have diaminopimelate dehydrogenase. Journal of General Microbiology 131, 2145-2152.

Baumann, L., Okamoto, K., Unterman, B. M., LYNCh, M. J. \& BaumanN, P. (1984). Phenotypic characterization of Bacillus thuringiensis and Bacillus cereus. Journal of Invertebrate Pathology 44, 329-341.

Baumann, P., BaumanN, L., Bowditch, R. D. \& Broadwell, A. H. (1987). Cloning of the gene for the larvicidal toxin of Bacillus sphaericus 2362 : evidence for a family of related sequences. Journal of Bacteriology, 169, 4061-4067.

BRoWNBRIDGE, M. \& MARGaLIT, J. (1987). Mosquito-active strains of Bacillus sphaericus isolated from soil and mud samples collected in Israel. Journal of Invertebrate Pathology 50, 106-112.

Claus, D. \& Berkeley, R. C. W. (1986). Genus Bacillus Cohn 1872. In Bergey's Manual of Systematic Bacteriology, vol. 2, pp. 1105-1141. Edited by P. H. A. Sneath. Baltimore: Williams \& Wilkins.

Cowan, S. T. (1974). Cowan and Steel's Manual for the Identification of Medical Bacteria, 2nd edn. Cambridge: Cambridge University Press.

ESDERS, T. W. \& LYNN, S. Y. (1985). Purification and properties of creatinine iminohydrolase from Flavobacterium filamentosum. Journal of Biological Chemistry 260, 3915-3922.
Gordon, R. E., Haynes, W. C. \& Pang, C. H.-N. (1973). The Genus Bacillus. Washington, DC: United States Department of Agriculture.

HINDLEY, J. \& BERRY, C. (1987). Identification, cloning and sequence analysis of the Bacillus sphaericus $159341.9 \mathrm{kD}$ larvicidal toxin gene. Molecular Microbiology 1, 187-194.

Kalfon, A., Lugten, M. \& Margalit, J. (1986). Development of selective media for Bacillus sphaericus and Bacillus thuringiensis var. israelensis. Applied Microbiology and Biotechnology 24, 240243.

KANDLER, O. \& WeISS, N. (1986). The genus Lactobacillus Beijerink 1901. In Bergey's Manual of Systematic Bacteriology, vol. 2, pp. 12081234. Edited by P. H. A. Sneath. Baltimore: Williams \& Wilkins.

KrYCH, V. K., Johnson, J. L. \& Yousten, A. A. (1980). Deoxyribonucleic acid homologies among strains of Bacillus sphaericus. International Journal of Systematic Bacteriology 30, 476-484.

Lysenko, O., Davidson, E. W., LACEY, L. A. \& Yousten, A. A. (1985). Five new larvicidal strains of Bacillus sphaericus from non-mosquito origins. Journal of the American Mosquito Control Association 1, 369371 .

Massie, J., RoberTs, G. \& White, P. J. (1985). Selective isolation of Bacillus sphaericus from soil by use of acetate as the only major source of carbon. Applied and Environmental Microbiology 49, 1478-1480.

MölleR, B., HipPe, H. \& GotTSChalk, G. (1986). Degradation of various amine compounds by mesophilic clostridia. Archives of Microbiology 145, 85-90.

NAKAMURA, L. K. (1984). Bacillus psychrophilus sp. nov., nom. rev. International Journal of Systematic Bacteriology 34, 121-123.

Priest, F. G. \& AleXander, B. (1988). A frequency matrix for the probabilistic identification of some bacilli. Journal of General Microbiology 134, 3011-3018.

Priest F. G., GoOdFellow, M. \& Todd, C. (1988). Numerical classification of the genus Bacillus. Journal of General Microbiology 134, 1847-1882.

RÜGER, H.-J. (1983). Differentiation of Bacillus globisporus, Bacillus marinus comb. nov., Bacillus aminovorans, and Bacillus insolitus. International Journal of Systematic Bacteriology 33, 157-161.

Russell, B. L., Jelley, S. A. \& Yousten, A. A. (1989). Carbohydrate metabolism in the mosquito-pathogen Bacillus sphaericus 2362 . Applied and Environmental Microbiology 55, 294-297.

SCHLEIFER, K. H. \& KANDLeR, O. (1972). Peptidoglycan types of bacterial cell walls and their taxonomic implications. Bacteriological Reviews 36, 407-477.

SINGER, S. (1987). Current status of the microbial larvicide Bacillus sphaericus. In Biotechnology in Invertebrate Pathology and Cell Culture, pp. 133-163. Edited by K. Maramosch. San Diego: Academic Press.

SINGER, S. (1988). Clonal populations with special reference to Bacillus sphaericus. Advances in Applied Microbiology 33, 47-74.

Skerman, V. B. D., McGowan, V. \& SNeath, P. H. A. (1980). Approved lists of bacterial names. International Journal of Systematic Bacteriology 30, 225-420.

SNEATH, P. H. A. (1979a). BASIC program for the identification of an unknown with presence-absence data against an identification matrix of percent positive characters. Computers and Geosciences 5 , 195-213.

SNEATH, P. H. A. (1979b). BASIC program for character separation indices from an identification matrix of percent positive characters. Computers and Geosciences 5, 349-357.

SNEATH, P. H. A. (1980a). BASIC program for the most diagnostic properties of groups from an identification matrix of percent positive characters. Computers and Geosciences 6, 21-26.'

SNEATH, P. H. A. (1980b). BASIC program for determining the best identification scores possible for the most typical example when compared with an identification matrix of percent positive characters. Computers and Geosciences 6, 27-34.

SNEATH, P. H. A. (1980c). BaSIC program for determining overlap between groups in an identification matrix of percent positive characters. Computers and Geosciences 6, 267-278.

SNEATH, P. H. A. \& JoHNSON, R. (1972). The influence on numerical taxonomic similarities of errors in microbiological tests. Journal of General Microbiology 72, 377-392. 
SNeATH, P. H. A. \& SoKal, R. R. (1973). Numerical Taxonomy. The Principles and Practice of Numerical Classification. San Francisco: W. H. Freeman \& Co.

Somerville, H. J. \& JoNes, M. L. (1972). DNA competition experiments within the Bacillus cereus group of bacilli. Journal of General Microbiology 73, 257-261.

StaCkebrandt, E., LudWig, W., Weizenegger, M., Dorn, S., MCGill, T. H., Fox, G. E., Woese, C. R., Schubert, W. \& SCHLEIFER, K. H. (1987). Comparative 16S rRNA oligonucleotide analysis and murein types of round-spore-forming bacilli and nonspore-forming relatives. Journal of General Microbiology 133, 25232529.

SzUlmajSTER, J. (1958). Bacterial fermentation of creatinine. I. Isolation of $\mathrm{N}$-methyl-hydantoin. Journal of Bacteriology 75, 633639.

Williams, S. T., Vickers, J. C. \& Goodfellow, M. (1985).
Application of new theoretical concepts to the identification of streptomycetes. In Computer-Assisted Bacterial Systematics, pp. 289306. Edited by M. Goodfellow, D. Jones \& F. G. Priest. London: Academic Press.

WISHART, D. (1978). Clustan User Manual. Version IC, Release 2, 3rd edn. Edinburgh: Edinburgh University Program Unit.

WORLD HEALTH ORGANIZATION (1985). Information Consultation on the Development of Bacillus sphaericus as a Microbial Larvicide. TDR/BCV/SPHAERICUS/85.3 (mimeo, doc). Rome: World Health Organization.

Yousten, A. A. (1984). Bacteriophage typing of mosquito-pathogenic strains of Bacillus sphaericus. Journal of Invertebrate Pathology 43, 124-125.

Yousten, A. A., Fretz, S. B. \& Jelley, S. A. (1985). Selective medium for mosquito-pathogenic strains of Bacillus sphaericus. Applied and Environmental Microbiology 49, 1532-1533. 